\title{
HUBUNGAN USIA IBU, OBESITAS DAN PENGGUNAAN KONTRASEPSI HORMONAL DENGAN KEJADIAN MIOMA UTERI
}

\section{RELATIONSHIP OF MATERNAL AGE, OBESITY AND HORMONAL CONTRACEPTIVE USE WITH INCIDENCE OF UTERINE MYOMA}

\author{
M. Ridwan, Gangsar Indah Lestari, Firda Fibrila \\ Poltekkes Kemenkes Tanjungkarang \\ Korespondensi: ridwan@poltekkes-tjk.ac.id
}

\begin{abstract}
Uterine myoma is a benign neoplasm derived from uterine muscles and connective tissue and ride it, known as fibromyoma, leomioma, or fibroid. The prevalence of uterine myoma in the World increased by more than 70-75\%. In Indonesia the incidence of uterine myoma is $2.39 \%$ - $11.70 \%$ of all gynecological patients treated. At Abdul Moeloek Hospital Bandar Lampung in 2016 by 51.5\%. In the hospital. General Ahmad Yani showed an increase over the last 2 years, namely: in 2018 as much as 18.6\% (22 cases of 118 gynecological diseases and in 2019 as much as 33\% (42 cases of 128 gynecological diseases. This study aims to find out the relationship of Maternal Age, Obesity and Hormonal Contraceptive Use with Uterine Myoma in hospitals. General A. Yani Metro and RSU Muhammadiyah Metro. This research is quantitative research collation with case control design. Research subjects were all women with a diagnosis of gynecological diseases. Data collection using questionnaires. The research sample of 101 respondents consisted of 45 case groups and 56 control groups. Sampling techniques are Quota Sampling and statistical testing using Chi Square test. The research was conducted at General A.Yani Hospital and Muhammadiyah Metro Hospital from May to October 2020. The results obtained a proportion of uterine myomas by $44.6 \%$, mothers at risk of uterine myoma by $48.5 \%$, obese mothers with uterine myomas as much as $47.5 \%$, mothers using hormonal contraceptives experienced uterine myoma as much as $54.4 \%$. Statistical test results there is a relationship of maternal age with the incidence of uterine myoma obtained $p$ value $=0.031$, there is a relationship of obesity with the incidence of uterine myoma obtained $p$ value $=0.007$ and there is a relationship of hormonal contraceptive use with the incidence of uterine myoma obtained $p$ value $=0.010$. Women of childbearing age are advised to reduce the consumption of red/half-cooked meat, increase the consumption of foods rich in vitamins $A$ and $D$, perform regular physical activity/exercise and switch contraceptives other than hormonal.
\end{abstract}

Keywords: Age, Obesity, Hormonal Contraceptives, Uteri Myoma

\begin{abstract}
ABSTRAK
Mioma uteri merupakan neoplasma jinak ini berasal dari otot uterus dan jaringan ikat dan menumpangnya, yang dikenal dengan istilah fibromioma, leomioma, ataupun fibroid. Prevalensi mioma uteri di Dunia meningkat lebih dari 70\%-75\%. Di Indonesia kejadian
\end{abstract}


mioma uteri sebesar 2,39\% - 11.70\% dari semua penderita ginekologi yang dirawat. Di RSUD Abdul Moeloek Bandar Lampung tahun 2016 sebesar 51,5\%. Di RSUD. Jend. Ahmad Yani menunjukkan kenaikan selama 2 tahun terakhir yaitu: tahun 2018 sebanyak 18,6\% (22 kasus dari 118 penyakit ginekologi dan tahun 2019 sebanyak 33\% (42 kasus dari 128 penyakit ginekologi. Penelitian ini bertujuan untuk mengetahui hubungan Usia Ibu, Obesitas dan Penggunaan Kontrasepsi Hormonal dengan Mioma Uteri di RSUD. Jend. A. Yani Metro dan RSU Muhammadiyah Metro. Penelitian ini merupakan penelitian kuantitatif kolerasi dengan rancangan case control. Subyek penelitian semua wanita dengan diagnosis penyakit ginekologi. Pengumpulan data menggunakan kuesioner. Sampel penelitian sebanyak 101 responden terdiri dari 45 kelompok kasus dan 56 kelompok kontrol. Teknik sampling adalah Quota Sampling dan uji statistik menggunakan uji Chi Square. Penelitian dilaksanakan di RSUD Jend. A.Yani dan RSU Muhammadiyah Metro bulan Mei sampai Oktober 2020. Hasil penelitian diperoleh proporsi mioma uteri sebesar $44,6 \%$, ibu berusia beresiko yang mengalami mioma uteri sebesar 48,5\%, ibu obesitas mengalami mioma uteri sebanyak 47,5\%, ibu menggunakan kontrasepsi hormonal mengalami mioma uteri sebanyak 54,4\%. Hasil uji statistik ada hubungan usia ibu dengan kejadian mioma uteri diperoleh $p$ value $=0,031$, ada hubungan obesitas dengan kejadian mioma uteri diperoleh $p$ value $=0,007$ dan ada hubungan penggunaan kontrasepsi hormonal dengan kejadian mioma uteri diperoleh $p$ value $=0,010$. Wanita pasangan usia subur disarankan mengurangi konsumsi daging merah/setengah matang, perbanyak konsumsi makanan kaya vitamin A dan D, lakukan aktivitas fisik/olah raga rutin dan beralih kontrasepsi selain hormonal.

\section{Kata Kunci : Usia, Obesitas, Kontrasepsi Hormonal, Mioma Uteri}

\section{PENDAHULUAN}

Masalah kesehatan reproduksi wanita, salah satunya adalah terjadi penyakit mioma uteri yang prevalensinya terus mengalami peningkatan walaupun sampai saat ini, belum diketahui secara pasti berapa insiden dan prevalensi mioma uteri. Diperkirakan prevalensi mioma uteri berkisar antara 5\%-21\% (Chiaffarino et al., 2017). Bahkan beberapa studi menyebutkan bahwa prevalensi mioma uteri mencapai $70 \%-77 \%$ tergantung pada populasi penelitian atau teknik diagnostik (Sparic et al.,2016). Di Indonesia mioma uteri ditemukan 2,39\%-11,7\% pada semua penderita ginekologi yang dirawat (Ahmad. Syahlani, 2014).

Penyebab kejadian mioma uteri belum diketahui secara pasti, diduga merupakan penyakit multifaktorial. Faktor penduga pertumbuhan mioma uteri antara lain umur, paritas, faktor ras dan genetik, usia menarche, obesitas, serta hormon estrogen dan progesteron (Manuaba, 2010).

Kejadian mioma uteri di RSUD H. Abdul Moeloek Bandar Lampung, 
pada tahun 2015 sebanyak 38 wanita, 24 $(63,16 \%)$ berusia $25-44$ tahun dan 14 $(36,8 \%)$ berusia 45-64 tahun. Tahun 2016 meningkat menjadi 62 wanita, $32(51,5 \%)$ berusia $25-44$ tahun, 28 $(45,2 \%)$ berusia 45-64 tahun, dan 2 (3.2\%) berusia >65 tahun (RSUD Dr. $\mathrm{H}$. Abdul Moeloek, 2017). Sedangkan di RSUD. Jend. A Yani Metro jumlah mioma uteri tahun 2017 sebanyak 28 dari 128 penyakit ginekologi $(21,8 \%)$, tahun 2018 sebanyak 22 kasus dari 118 penyakit ginekologi $(18,6 \%)$ dan tahun 2019 sebanyak 42 kasus dari 128 penyakit ginekologi (33 \%). Tujuan penelitian untuk mengetahui hubungan usia ibu, obesitas dan penggunaan kontrasepsi hormonal dengan kejadian mioma uteri.

\section{METODE}

Penelitian ini merupakan penelitian kuantitatif kolerasi dengan rancangan case control. Subyek penelitian semua wanita dengan diagnosis penyakit ginekologi. Sampel penelitian sebanyak 101 responden terdiri dari 45 kelompok kasus dan 56 kelompok kontrol. Teknik sampling adalah Quota Sampling yang dikumpulkan secara bersamaan di dua Rumah Sakit pada sampel kasus dan sampel kontrol yang memenuhi syarat kriteria inklusi dan eksklusi penelitian.
Pengumpulan data menggunakan kuesioner, analisis data secara univariat dan bivariat dengan uji statistik $C h i$ Square. Penelitian dilaksanakan di RSUD Jend. A. Yani Metro dan RSU Muhammadiyah Metro bulan Mei sampai Nopember 2020 dengan persetujuan laik etik dari komisi etik Poltekkes Tanjungkarang dengan Nomor: $\quad$ 240/KEPK-TJK/IV/2020 tanggal 06 April 2020.

\section{HASIL DAN PEMBAHASAN}

\section{Distribusi Mioma Uteri, Usia, Obesitas dan Penggunaan Kontrasepsi Hormonal}

Tabel 1. Distribusi Kejadian Mioma Uteri, Usia Ibu, Obesitas dan Penggunaan Kontrasepsi Hormonal

\begin{tabular}{lcc}
\hline Variabel Penelitian & $\mathrm{n}$ & $\%$ \\
\hline 1. Kejadian Mioma & & \\
Uteri & & \\
a. Mioma Uteri & 45 & 44,6 \\
b. Tidak Mioma & 56 & 55,4 \\
&
\end{tabular}

2. Usia Ibu :
a. Beresiko (35-45 $56 \quad 55,4$ tahun)
b. Tidak Beresiko $52 \quad 51,5$ $(<35->45$ tahun

3. Obesitas :
a. Obesitas
$48 \quad 47,5$
b. Tidak Obsesitas $53 \quad 52,5$

4. Penggunaan

Kontrasepsi

Hormonal: $\quad 65 \quad 64,4$

a. Hormonal $36 \quad 35,6$

b. Non Hormonal

Total $101 \quad 100,0$


Berdasarkan tebel 1, menunjukkan bahwa sebanyak 44,6\% ibu mengalami mioma uteri, sebanyak $48,5 \%$ ibu dengan usia beresiko (35-45 tahun), sebanyak $\quad 47,5 \% \quad$ ibu mengalami obesitas dan sebanyak $64,4 \%$ ibu menggunakan kontrasepsi hormonal.

\section{Usia Ibu dan Kejadian Mioma Uteri}

Tabel 2. Hubungan Usia Ibu dengan Kejadian mioma Uteri

\begin{tabular}{|c|c|c|c|c|c|}
\hline \multirow[b]{2}{*}{ Usia Ibu } & $\begin{array}{r}\text { Keja } \\
\text { Miom }\end{array}$ & 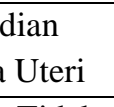 & \multirow[b]{2}{*}{$\mathrm{Jml}$} & \multirow{2}{*}{$\begin{array}{c}\mathrm{P} \\
\text { Value }\end{array}$} & \multirow{2}{*}{$\begin{array}{l}\text { OR CI } \\
(95 \%)\end{array}$} \\
\hline & $\begin{array}{c}\text { Mioma } \\
\text { Uteri }\end{array}$ & $\begin{array}{c}\text { Tidak } \\
\text { Mioma } \\
\text { Uteri }\end{array}$ & & & \\
\hline $\begin{array}{l}\text { Beresiko } \\
\text { (35-45 Thn) }\end{array}$ & $\begin{array}{c}27 \\
(55,1)\end{array}$ & $\begin{array}{c}22 \\
(44,9)\end{array}$ & $\begin{array}{c}49 \\
(100)\end{array}$ & \multirow{3}{*}{0,031} & \multirow{3}{*}{$\begin{array}{c}2,318 \\
(1,039- \\
5,170)\end{array}$} \\
\hline $\begin{array}{l}\text { Tidak } \\
\text { Beresiko } \\
(<35->45 \text { thn })\end{array}$ & $\begin{array}{c}18 \\
(34,6)\end{array}$ & $\begin{array}{c}34 \\
(65,3)\end{array}$ & $\begin{array}{c}52 \\
(100)\end{array}$ & & \\
\hline Total & $\begin{array}{c}45 \\
(44,6)\end{array}$ & $\begin{array}{c}56 \\
(55,4)\end{array}$ & $\begin{array}{c}101 \\
(100)\end{array}$ & & \\
\hline
\end{tabular}

Berdasarkan tebel 2, penelitian terhadap 101 ibu yang mengalami mioma uteri sebanyak $55,1 \% \quad$ (27) berusia beresiko. Hasil uji statistik diperoleh nilai $p$ value $=0,031$ ( $p$ value $\leq \alpha$ ), maka Ho ditolok yang berarti secara statistik ada hubungan antara usia ibu dengan kejadian mioma uteri. Hasil analisis diperoleh OR 2,318 artinya ibu dengan usia beresiko (35-45 tahun) memiliki peluang mengalami mioma uteri sebesar 2,3 kali dibanding dengan ibu berusia tidak beresiko.

Penelitian ini sesuai oleh Rasela Kurniaty dan Sunarsih (2016) pada penelitiannya di RSUD DR. H. Abdul Moeloek Bandar Lampung juga menemukan sebanyak 72,0\% (36) ibu pada kelompok usia beresiko dan $28,0 \%$ (14) ibu dengan kelompok usia tidak beresiko. Hasil uji satatistik diperoleh nilai $p$-value $=0,023(<0,05)$ sehingga disimpulkan terdapat hubungan antara usia ibu dengan kejadian mioma uteri. Hal sama juga ditemukan Meyrawati, Mustika Dewi (2017) pada penelitiannya di RSU PKU Muhammadiyah Kota Yogyakarta Tahun 2015-2016 diperoleh $p$ value $=0,001$ sehingga disimpulkan terdapat hubungan usia dengan kejadian mioma uteri.

Menurut Setiati, Eni (2009), mioma uteri jarang terjadi pada usia < 20 tahun dan belum pernah dilaporkan terjadi sebelum menarche serta pada menopause angka kejadian sekitar $10 \%$. Mioma uteri juga paling sering $(<25 \%)$ ditemukan pada wanita umur 35-45 tahun serta jarang terjadi pada wanita umur 20 tahun dan pasca menopause (Ahmad, Syahlani 2014). EA Stewart, CL Cookson, RA Gandolfo, R Schulze- 
Rath (2017) melaporkan wanita berusia 40-50 atau 51-60 tahun 10 kali lebih memiliki uterin fibrosis dari mereka berusia 21-30 tahun. Tetapi pada usia pasca menopouse (>60 tahun), resiko uterine fibrosia menurun. Berdasarkan hasil USG di Inggris menemukan wanita berusia $>40$ tahun 4 lebih memiliki uterine fibrosis daripada mereka yang berusia < 40 tahun. Menurut Pasinggi, wegey dan Rarung (2015) menjelaskan beberapa alasan yang mendasari mioma uteri terdiagnosis pada usia $>40$ tahun antara lain karena peningkatan pertumbuhan atau peningkatan gejala yang dirasakan dari mioma uteri yang telah ada jauh sebelum gejala tersebut dirasakan oleh pasien saat ini. Hal ini juga patut dicurigai karena apabila mioma uteri masih berkembang setelah menopouse akan memiliki kemungkinan untuk tumbuh menjadi suatu keganasan sehingga perlu adanya tindakan histrektomi.

Berdasarkan temuan penelitian ini menunjukkan kejadian mioma uteri umumnya terjadi pada usia reproduksi. Petugas kesehatan perlu memberikan menganjurkan ibu untuk melakukan cek kesehatan secara rutin sebagai upaya deteksi dini untuk pencegahan timbulnya gangguan ginekologi dan faktor predisposisi menyebabkan timbulnya mioma uteri terutama ibu dengan usia beresiko (35-45 tahun).

\section{Obesitas dan Kejadian Mioma Uteri}

Tabel 3. Hubungan Obesitas dengan Kejadian mioma Uteri

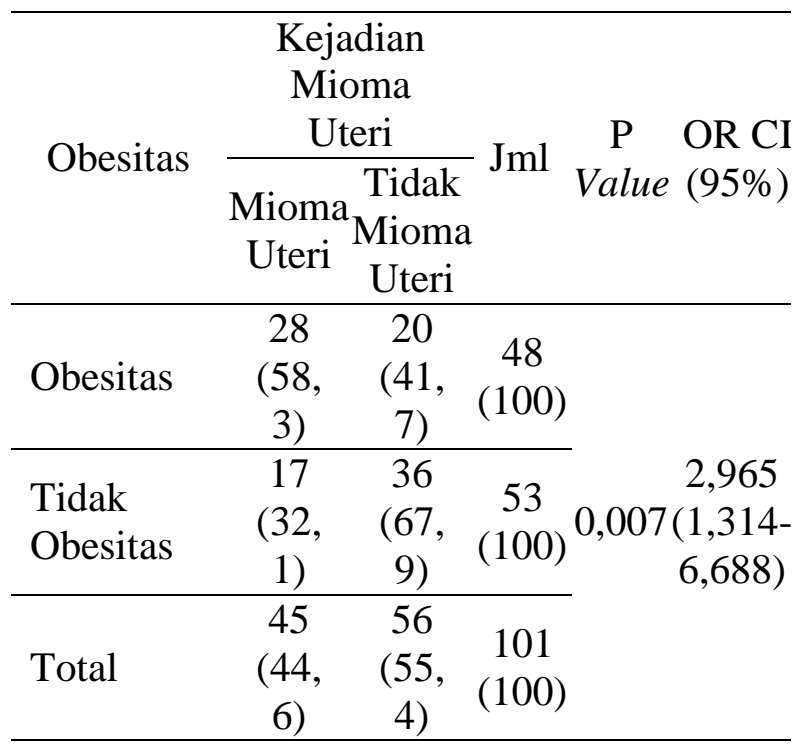

Berdasarkan tebel 3, penelitian terhadap $101 \mathrm{ibu}$ yang mengalami mioma uteri sebanyak $58,3 \%$ (28) terjadi pada ibu yang obesitas, sedangkan pada ibu yang tidak mengalami mioma uteri sebanyak $41,9 \%$ (20) terjadi pada ibu yang obesitas. Hasil uji statistik diperoleh nilai $p$ value $=0,007(p$ value $\leq \alpha)$, berarti secara statistik ada hubungan antara obesitas dengan kejadian mioma uteri. Hasil analisis diperoleh OR 2,965 artinya ibu yang obesitas memiliki 
peluang mengalami mioma uteri sebesar 2,9 kali dibanding dengan ibu yang tidak obesitas.

Hasil penelitian ini hampir sama dibanding penelitian Ningrum N.W, R. Topan Aditya Rahman, Mahmudah (2016) di Ruang Poli Kandungan RSUD dr. H. Moch. Ansari Saleh Banjarmasin menemukan proporsi ibu dengan obesitas (IMT $\geq 27,0$ ) lebih banyak mengalami mioma uteri yaitu $64,3 \%$ (54) ibu. Hal yang sama juga ditemukan oleh Kusumaningsih DA (2018) pada penelitinnya di RSUD Dr. Soetomo Surabaya dari 142 responden sebanyak $54,2 \%$ ( 77) ibu yang mengalami obesitas terjadi mioma.

Penelitian ini sesuai dengan penelitian Prawita, Mirna dan Wulandari, Diah (2016) di RSUD Panembahan Senopati Bantul tahun 2014 dengan hasil Uji statistik didapatkan $p$ value $=0,002 \quad(<0,05)$ artinya ada hubungan IMT dengan kejadian mioma uteri dan diperoleh OR 3,325 artinya IMT berlebih memiliki risiko tiga kali lebih besar mengalami mioma uteri $>3 \mathrm{~cm}$ dibandingkan dengan IMT normal.

Menurut Setiati, Eni (2009) pada dasarnya obesitas terjadi karena energi yang didapat lewat makanan melebihi energi yang dikeluarkan. Ketidakseimbangan ini didapat dari berlebihnya energi yang diperoleh dan atau berkurangnya energi yang dikeluarkan untuk metabolisme tubuh, thermolegulasi dan aktivitas fisik. Estrogen dapat dihasilkan secara exogen (luar ovarium) seperti sel-sel adipose (sel lemak) yang berhubungan dengan konversi hormon androgen menjadi estrogen oleh enzim aromatase di jaringan lemak, sehingga terjadi peningkatan jumlah estrogen tubuh pada wanita dengan berat badan berlebih.

Prawirohardjo, Sarwono; Anwar Mochamad; Baziad Ali; Prabowo R. Prajitno (2011), mengemukakan ukuran besar kecilnya mioma uteri juga dipengaruhi oleh jumlah kalori. Makin gemuk seseorang, makin banyak timbunan kalorinya dan membuat mioma tumbuh cepat.

Hal ini karena Obesitas dianggap sebagai suatu faktor risiko terjadinya mioma uteri (Manta et.al., 2016). Menurut McWilliams dan Chennathukuzhi, (2017), menyatakan bahwa IMT berkorelasi dengan meningkatnya insidensi mioma uteri dimana untuk setiap penambahan $10 \mathrm{~kg}$ berat badan, risiko terjadinya mioma uteri meningkat lebih dari $20 \%$. Selain 
itu, studi lain juga secara spesifik menyatakan bahwa adanya kenaikan $6 \%$ risiko menderita mioma uteri untuk setiap unit kenaikan Indeks Massa Tubuh (IMT). Penemuan serupa juga melaporkan resiko mioma uteri meningkat pada wanita yang memiliki lemak lebih dari 30\% (Manuaba, 2010). Hal ini sesuai yang dikemukakan oleh Tak et al., (2016), peningkatan dalam obesitas diikuti oleh peningkatan dalam konversi androgen adrenal yang bersirkulasi menjadi estrone akibat akumulasi jaringan adiposa.

Dari uraian teori diatas dapat di asumsikan bahawa kelebihan lemak atau kurang aktivitas fisik yang menyebabkan obesitas menjadi berisko untuk menderita mioma. Hal ini mungkin berhubungan dengan konversi hormon androgen menjadi estrogen oleh enzim aromatase dijaringan lemak. Hasilnya terjadi peningkatan jumlah estrogen tubuh, dimana hal ini dapat menerangkan hubungannya dengan peningkatan prevalensi dan pertumbuhan mioma uteri.

Petugas kesehatan perlu menganjurkan ibu untuk mengkonsumsi makanan yang seimbang dan berolah raga rutin yang disesuaikan dengan kondisi obesitas ibu.

\section{Penggunaan Kontrasepsi \\ Hormonal dan Kejadian Mioma Uteri}

Tabel 4. Hubungan Penggunaan

Kontrasepsi Hormonal dengan

Kejadian mioma Uteri

\begin{tabular}{|c|c|c|c|c|c|}
\hline \multirow{2}{*}{$\begin{array}{c}\text { Penggunaan } \\
\text { Kontrasepsi } \\
\text { Hormonal }\end{array}$} & $\begin{array}{r}\text { Keja } \\
\text { Miom }\end{array}$ & $\begin{array}{l}\text { dian } \\
\text { Uteri }\end{array}$ & \multirow[b]{2}{*}{$\mathrm{Jml}$} & \multirow[b]{2}{*}{$\begin{array}{c}\mathrm{P} \\
\text { Value }\end{array}$} & \multirow[b]{2}{*}{$\begin{array}{l}\text { OR CI } \\
(95 \%)\end{array}$} \\
\hline & $\begin{array}{c}\text { Mioma } \\
\text { Uteri }\end{array}$ & $\begin{array}{c}\text { Tidak } \\
\text { Mioma } \\
\text { Uteri }\end{array}$ & & & \\
\hline Hormonal & $\begin{array}{c}35 \\
(58,8)\end{array}$ & $\begin{array}{c}30 \\
(46,2)\end{array}$ & $\begin{array}{c}65 \\
(100)\end{array}$ & \multirow{3}{*}{0,010} & \multirow{3}{*}{$\begin{array}{c}3,033 \\
(1,262- \\
7,294)\end{array}$} \\
\hline $\begin{array}{l}\text { Tidak } \\
\text { Hormonal }\end{array}$ & $\begin{array}{c}10 \\
(27,8)\end{array}$ & $\begin{array}{c}26 \\
(72,2)\end{array}$ & $\begin{array}{c}36 \\
(100)\end{array}$ & & \\
\hline Total & $\begin{array}{c}45 \\
(44,6)\end{array}$ & $\begin{array}{c}56 \\
(55,4)\end{array}$ & $\begin{array}{c}101 \\
(100)\end{array}$ & & \\
\hline
\end{tabular}

Berdasarkan tebel 4, penelitian terhadap $101 \mathrm{ibu}$ yang mengalami mioma uteri sebanyak $58,8 \% \quad$ (35) menggunakan kontrasepsi hormonal, sedangkan ibu yang tidak mengalami mioma uteri sebanyak 46,2\% (30) terjadi pada ibu tidak menggunakan kontrasepsi hormonal. Hasil uji statistik diperoleh $p$ value $=0,010 \quad(<0,05)$, berarti secara statistik ada hubungan penggunaan kontrasepsi hormonal dengan kejadian mioma uteri. Hasil analisis diperoleh OR 3,033 artinya pada ibu yang menggunakan kontrasepsi hormonal memiliki peluang mengalami mioma uteri sebesar 3,0 kali dibanding dengan ibu yang tidak menggunakan kontrasepsi hormonal.

Penelitian ini sesuai dengan penelitian Fahrunniza. Nida, Heny 
Astutik, Moch. Gatot Heri Praptono (2014) di Poli Kandungan RSUD "Kanjuruhan" Kepanjen Kabupaten Malang, hasil uji statistik menemukan nilai $p$-value $=0,000(<0,05)$ sehingga disimpulkan terdapat hubungan antara penggunaan kontrasepsi hormonal dengan kejadian mioma uteri.

Penyebab kejadian mioma uteri belum diketahui secara pasti, diduga merupakan penyakit multifaktorial. Sebagai salah satu pencetus mioma uteri, hormon estrogen dan progesteron dapat diperoleh melalui kontrasepsi yang bersifat hormonal. Menurut Meyer de Snoo dalam teori Cell nest atau teori genitoblast dalam Prawirohardjo, Sarwono; Anwar Mochamad; Baziad Ali; Prabowo R. Prajitno (2011), menyatakan bahwa estrogen dapat memicu pertumbuhan mioma uteri karena mioma uteri kaya akan reseptor estrogen. Menurut Nugroho, Taufan; Utama Bobby Indra (2014), mioma uteri dipengaruhi oleh kadar estrogen. Fibroid seringkali bertambah besar selama kehamilan dan mengecil setelah menopause. Selama penderita masih mengalami siklus menstruasi, kemungkinan fibroid akan terus tumbuh meskipun pertumbuhannya sangat lambat.
Lamanya penggunaan kontrasepsi juga dapat mempengaruhi ukuran dari mioma uteri yang berkaitan dengan lamanya miometrium terpapar dengan hormon yang mempengaruhi pertumbuhan mioma uteri. Penelitian ini menemukan bahwa lama penggunaan alat kontrasepsi hormonal umumnya selama $>5$ tahun dengan $48,5 \%$ jenis kontrasepsi hormonal yang dipakai kontrasepsi suntik.

Paling tidak terdapat dua komponen yang berbeda yang berkontribusi dalam pertumbuhan mioma uteri, yaitu: transformasi miositmiosit normal menjadi miosit yang tidak normal, akibat mutasi somatik dan pertumbuhan miosit-miosit yang tidak normal menjadi tumor yang nampak secara klinis. Stem cells miometrium diketahui tumbuh menjadi mioma uteri di bawah pengaruh beberapa hormon. Sel-sel pada mioma berproliferasi dengan kecepatan sedang dan pertumbuhannya tergantung dari hormon-hormon steroid yang diproduksi oleh ovarium yaitu estrogen dan progesteron. Adanya ketergantungan terhadap hormonhormon ini yang menyebabkan menciutnya sebagian besar kasus mioma uteri setelah menopause. Selain 
itu, estrogen estradiol yang poten akan menginduksi produksi reseptor progesteron melalui reseptor estrogen alfa (ER- $\alpha)$ Reseptor-reseptor progesteron ini merupakan komponen penting dalam respons jaringan mioma terhadap progesteron yang disekresi oleh ovarium. Oleh karenanya, baik progesteron dan reseptor progesteron sangat diperlukan bagi terjadinya pertumbuhan tumor, peningkatan proliferasi sel, serta bagi ketahanan dan peningkatan pembentukan matriksmatriks ekstraseluler. Estrogen dan ER$\alpha$ sendiri tidaklah cukup untuk pertumbuhan mioma uteri tanpa adanya progesteron dan reseptor progesteron (Audric Albertus, 2020).

Pertumbuhan mioma diperkirakan memerlukan waktu 3 tahun agar dapat mencapai ukuran sebesar tinju, akan tetapi beberapa kasus ternyata tumbuh cepat, walaupun seringkali kejadian mioma uteri diketahui secara tidak sengaja saat USG kehamilan, namun tidak jarang pula mioma uteri diketahui saat pasien mengalami keluhan. Keluhan nyeri yang dirasakan pasien biasanya timbul saat ukuran mioma uteri mulai membesar (Prawirohardjo, Sarwono; Anwar Mochamad; Baziad Ali; Prabowo R. Prajitno, 2011),
Petugas kesehatan menganjurkan ibu untuk konsultasi ke dokter kandungan agar dapat dilakukan pemeriksaan USG sehingga penyakit lebih dini diketahui dan ibu tidak mengalami keluhan yang lebih komplikatif, perlu juga disarankan ibu untuk beralih metode kentrasepsi selain kontrasepsi hormonal.

\section{SIMPULAN}

Kejadian mioma uteri sebesar 48,5\% ibu berusia beresiko, sebesar 47,5\% ibu mengalami obesitas dan sebesar $54,4 \%$ ibu menggunakan kontrasepsi hormonal. Ada hubungan usia ibu, obesitas dan penggunaan kontrasepsi hormonal dengan kejadian mioma uteri. Wanita pasangan usia subur disarankan mengkonsumsi makanan yang seimbang, lakukan aktivitas fisik/olah raga rutin yang disesuaikan dengan kondisi obesitasnya dan beralih metode kontrasepsi selain hormonal bagi yang menggunakan kontrasepsi lebih dari 5 tahun.

\section{UCAPAN TERIMAKASIH}

Ucapan terima kasih disampaikan kepada Poltekkes Kemenkes Tanjungkarang, RSUD A. Yani Kota Metro dan RSU Muhammadhiyah Metro yang telah memfasilitasi kegiatan penelitian ini. 


\section{DAFTAR PUSTAKA}

Ahmad Syahlani, 2014. Faktor-Faktor Yang Berhubungan dengan Kejadian Mioma Uteri. Dinamika Kesehatan, Vol 7 No. 1 Juli 2016. https://ojs.dinamikakesehatan.unis m.ac.id. Diakeses [19/10/2020]

Audric Albertus. 2020. Etiologi dan Pathofisiologi Mioma Uteri. Alomedika.

https://www.alomedika.com/penya kit/obstetrik-danginekologi/mioma-uteri/etiologipatofisiologi Diakeses [19/10/2020]

Chiaffarino, F., Cipriani, S., Ricci, E., La Vecchia, C., Chiantera, V., Bulfoni, A., Parazzini, F., 2017. Alcohol Consumption And Risk Of Uterine Myoma: A Systematic Review And Meta Analysis. Plos One 12 (11), 1-11. https://doi.org/10.1371/journal. pone. 0188355

EA Stewart, CL Cookson, RA Gandolfo, R Schulze-Rath, 2017, Epidemiology of Uterine Fibroids: A Systematic Review. International Journal of Obstetrics and Gynaecology. https://obgyn.onlinelibrary.wiley.co m/doi/full/10.1111/1471$\underline{0528.14640}[19 / 02 / 2020]$

Fahrunniza. Nida, Heny Astutik, Moch. Gatot Heri Praptono, 2014. Kejadian Mioma Uteri Pada Akseptor Hormonal. Poltekkes Kemenkes Malang. Jurnal informasi kesehatan indonesia (JIKI) Vo.1 No.1 Mei 2015: 69-75. https://adoc.pub/kejadian-miomauteri-pada-akseptor-hormonal.html [diakses: 12-12-2019]

Kusumaningsih, Dyah Ayu. 2018. Hubungan indeks massa tubuh (IMT) dengan kejadian mioma uteri pada wanita usia subur di RSUD DR. Soetomo Surabaya. Prodi Pendidikan Bidan Fakultas Kedokteran Universitas Airlangga. https://www.academia.edu/signup?a id=57476668 diakses: 12-12-2019

Manuaba, 2010. Ilmu Kebidanan Penyakit Kandungan dan Keluarga Berencana Untuk Pendidikan Bidan. Jakarta: EGC.

Manta, L., Suciu, N., Toader, O., Purcărea, R. M., Constantin, A. and Popa, F. 2016, 'The etiopathogenesis of uterine fibromatosis', Journal of Medicine and Life, vol. 9, no. 1, pp. 39-23.

McWilliams, M. M. and Chennathukuzhi, V. M. 2017, 'Recent advances in uterine fibroid etiology', Seminar in Reproductive Medicine, vol. 35, no.2, pp. 181189.

Meyrawati, Mustika Dewi. 2017. Faktor-faktor yang berhubungan dengan kejadian mioma uteri di DRU PKU Muhammadiyah Kota Yogyakarta Tahun 2015-2016. Prodi Bidan Pendidik Fakultas Ilmu Kesehatan Universitas Aisyiyah 
Yogyakarta.

https://www.digilib.unisayogya.ac.i d/2764/1 diakses: 12-12-2019

Nugroho, Taufan; Utama Bobby Indra. 2014. Masalah Kesehatan Reproduksi Wanita, Nuha Medika, Yogyakarta, 384 halaman

Ningrum N.W, R. Topan Aditya Rahman, Mahmudah. 2016. Hubungan Obesitas Dan Riwayat Keluarga Dengan Kejadian Mioma Uteri Di Ruang Poli Kandungan RSUD dr.H.Moch. Ansari Saleh Banjarmasin Tahun 2016. Skripsi Sekolah Tinggi Ilmu Kesehatan Sari Mulia Banjarmasin. Jurna; Dinamika Kesehatan Vol.9 N0.1 Juli 2018. https://www.ojs.dinamikakesehata n.unism.ac.id/index.php/dksm/arti cle/view/307 diakses: 12-12-2019

Pasinggi S, Wegey $\mathrm{F}$, Rarung $\mathrm{M}$. (2015). Prevalensi mioma uteri berdasarkan umur di RSUP Prof.Dr.R.D. Kandou Manado. Journal e clinic (eCl) 2015:3:9-13

Pratiwi, Lilis, Eddy Suparman, Freddy Wagery. 2013. Hubungan Usia Reproduksi dengan Kejadian Mioma Uteri di RSUP Prof. DR. R.D. Kandou Manado. Vol I No 1. Jurnal e-Clinic. diakses: 12-122019

Prawita, Mirna dan Wulandari, Diah. 2016. Hubungan indeks Massa Tubuh dengan Kejadian Mioma Uteri di Rumah Sakit Umum
Daerah (RSUD) Penembahan Senopati Bantul Tahun 2014. Tugas Akhir D.IV Bidan Pendidik. Universitas Gadjah Mada Yogyakarta. http://etd.repository.ugm.ac.id/pene litian/detail/94272 $\quad[10$ Oktober 2019]

Prawirohardjo, Sarwono; Anwar Mochamad; Baziad Ali; Prabowo R. Prajitno (Ed.), 2011, Ilmu Kandungan Edisi III, PT Bina Pustaka, Jakarta, 603 halaman\

Rasela. K dan Sunarsih. 2016. FaktorFaktor yang berhubungan dengan kejadian mioma uteri di RSUD DR. H. Abdul Moeloek Bandar Lampung Tahun 2016. Jurnal Kebidanan Universitas Malahayati. Vol.4 No.3 Juli 2018:100-105. https://www.ejurnalmalahayati.ac.i d/index.php/kebidanan/issue/view/ Kualitas tidur bayi, mioma uteri. Diakses: 29-11-2019

RSUD DR. H. Abdul Moeloek. 2017. Rekam Medik RSUD Dr. H. Abdul Moeleok Provinsi Lampung.

Sparic, R., Mirkovic, L., Malvasi, A., Tinelli, A., 2016. Epidemiology of Uterine Myomas: A Review. Int. J. Fertil. Steril. 9 (4), 424-435. https://www.ncbi.nlm.nih.gov/pmc/ articles/PMC4793163/ Diakeses [19/10/2020]

Setiati, Eni. 2009, Kanker Ganas Pembunuh Wanita, ANDI, Yogyakarta, 122 halaman 
Tak, Y. J., Lee, S. Y., Park, S. K., Kim, Y. J., Lee, J. G., Jeong, D. W., Kim, S.C., Kim, I. J. and Yi, Y. H. 2016, 'Association between uterine leiomyoma and metabolic syndrome in parous premenopausal women', Medicine, Nov. vol. 95, no. $46, \quad$ pp. 1-7. https://www.ncbi.nlm.nih.gov/pmc/ articles/PMC5120917/ 